Meta

Journal des traducteurs

Translators' Journal

\title{
Ambivalence, Gender, and Censorship in two Spanish Translations of Little Women
}

\section{Marcello Giugliano et Elia Hernández Socas}

Volume 64, numéro 2, août 2019

URI : https://id.erudit.org/iderudit/1068197ar

DOI : https://doi.org/10.7202/1068197ar

Aller au sommaire du numéro

\section{Éditeur(s)}

Les Presses de l’Université de Montréal

\section{ISSN}

0026-0452 (imprimé)

1492-1421 (numérique)

Découvrir la revue

Citer cet article

Giugliano, M. \& Hernández Socas, E. (2019). Ambivalence, Gender, and Censorship in two Spanish Translations of Little Women. Meta, 64(2), 312-333. https://doi.org/10.7202/1068197ar
Résumé de l'article

Le présent article constitue une analyse de deux traductions en espagnol du célèbre roman Little Women, de Louisa May Alcott. La première traduction date de 1948 et la seconde de 2004. Elles sont toutes les deux intitulées Mujercitas. Nous avons choisi cette oeuvre pour plusieurs raisons. Tout d'abord, le roman Little Women a été publié pour la première fois en 1868-1869 et malgré le succès immédiat qu'il rencontra aux États-Unis, il fut réédité et modifié par les éditeurs et par l'auteure en 1880. Il en résulta une version édulcorée et censurée de la première édition dans laquelle étaient neutralisés la plupart des éléments subversifs et controversés de la première version, notamment ceux liés à l'image et au rôle de la femme dans la société nord-américaine de l'époque. La première traduction en Espagne date de 1948, soit un peu moins de dix ans après la fin de la guerre d'Espagne, en pleine période franquiste, à une époque où la littérature, espagnole comme étrangère, était largement censurée. Cette traduction a été soumise à divers degrés et types de censure, comme l'autocensure de la part du traducteur et la censure institutionnelle. La comparaison de cette version avec une traduction plus récente, présentée comme la première version intégrale en espagnol du texte original de 1868-1869, permet d'identifier les éléments liés à l'image de la femme qui ont été censurés dans les traductions. Cela nous permet de nous pencher sur l'importation et l'adaptation à l'idéologie de l'Espagne franquiste du discours idéologique contenu dans le texte source sur la position et le rôle de la femme dans la société, ainsi que sur les importantes modifications apportées à ce même discours dans la seconde traduction analysée, publiée un demi-siècle plus tard, soit trente ans après la chute du régime franquiste et du début de l'ère démocratique en Espagne.
Ce document est protégé par la loi sur le droit d'auteur. L’utilisation des services d'Érudit (y compris la reproduction) est assujettie à sa politique d'utilisation que vous pouvez consulter en ligne.

https://apropos.erudit.org/fr/usagers/politique-dutilisation/ 


\title{
Ambivalence, Gender, and Censorship in two Spanish Translations of Little Women
}

\author{
MARCELLO GIUGLIANO \\ Universität Leipzig, Leipzig, Germany \\ marcello.giugliano@uni-leipzig.de.de \\ ELIA HERNÁNDEZ SOCAS \\ Universität Leipzig, Leipzig, Germany \\ socas@uni-leipzig.de
}

\begin{abstract}
RÉSUMÉ
Le présent article constitue une analyse de deux traductions en espagnol du célèbre roman Little Women, de Louisa May Alcott. La première traduction date de 1948 et la seconde de 2004. Elles sont toutes les deux intitulées Mujercitas. Nous avons choisi cette œuvre pour plusieurs raisons. Tout d'abord, le roman Little Women a été publié pour la première fois en 1868-1869 et malgré le succès immédiat qu'il rencontra aux États-Unis, il fut réédité et modifié par les éditeurs et par l'auteure en 1880. II en résulta une version édulcorée et censurée de la première édition dans laquelle étaient neutralisés la plupart des éléments subversifs et controversés de la première version, notamment ceux liés à l'image et au rôle de la femme dans la société nord-américaine de l'époque. La première traduction en Espagne date de 1948, soit un peu moins de dix ans après la fin de la guerre d'Espagne, en pleine période franquiste, à une époque où la littérature, espagnole comme étrangère, était largement censurée. Cette traduction a été soumise à divers degrés et types de censure, comme l'autocensure de la part du traducteur et la censure institutionnelle. La comparaison de cette version avec une traduction plus récente, présentée comme la première version intégrale en espagnol du texte original de 1868-1869, permet d'identifier les éléments liés à l'image de la femme qui ont été censurés dans les traductions. Cela nous permet de nous pencher sur l'importation et l'adaptation à l'idéologie de l'Espagne franquiste du discours idéologique contenu dans le texte source sur la position et le rôle de la femme dans la société, ainsi que sur les importantes modifications apportées à ce même discours dans la seconde traduction analysée, publiée un demisiècle plus tard, soit trente ans après la chute du régime franquiste et du début de l'ère démocratique en Espagne.
\end{abstract}

\begin{abstract}
In our study we analyse two Spanish translations of Louisa May Alcott's well-known novel Little Women. The first one was published in 1948, the second in 2004, both titled Mujercitas. The choice fell to this book for several reasons. To begin, Little Women was first published in 1868-1869 and, though it was an immediate success in the USA, it was reedited and modified by the publisher and the author in 1880. The result was a softened and censored version that rounded the edges of the first edition and toned down its subversive or controversial elements, especially in relation to the image and role of women in North American society at that time. The first translation in Spain was published in 1948, appearing at a particularly dramatic moment in Spanish history, in the decade after the end of the Civil War, when censorship of foreign and home literature was particularly harsh. Mujercitas (1948) may thus be the product of a second and even third degree of censorship (the translator's self-censorship and the institutional censorship respectively). By comparing this translation with a more recent one, which, moreover, was advertised in the Spanish publishing market as being the first Spanish translation of
\end{abstract}


the original 1868-1869 source text, we attempt to identify the censored elements in the translations by focusing more specifically on the image of womanhood in the novel. The result should prompt reflections on how the ideological discourse behind the source text(s), related to the position and role of women in society, was imported and adapted to the dominant ideology in Franco's Spain and whether such discourse has undergone significant changes in the second translation, half a century after the first one and almost thirty years after the end of the regime and of the beginning of the democratic era in Spain.

\section{RESUMEN}

En el presente trabajo analizamos dos traducciones al español del clásico de Louisa May Alcott Little Women: la primera data de 1948 y la segunda de 2004, ambas con el título de Mujercitas. Los motivos que justifican esta selección son varios: por un lado, Little Women fue publicada por primera vez en 1868-1869 y, a pesar del éxito inmediato que tuvo en los Estados Unidos, fue reeditada y modificada por los editores y la propia autora en 1880. El resultado de esta segunda edición fue una versión edulcorada y censurada de la primera que suavizaba todos aquellos elementos subversivos y controvertidos, sobre todo aquellos relacionados con la imagen y el papel de la mujer en la sociedad norteamericana de la época. La primera traducción en España aparece en 1948, es decir, poco menos de una década después del final de la Guerra Civil Española y en plena época franquista, en un momento en que se aplicaba con dureza la censura tanto a la literatura extranjera como a la nacional. Esta traducción fue sometida a diferentes grados y tipos de censura, como, por ejemplo, la autocensura del traductor y la censura institucional. La comparación con una traducción más reciente, que, además, se presenta como la primera "versión íntegra" en castellano del original de 1868-1869, nos permite identificar los elementos relacionados con la imagen de la mujer que han sido censurados en las traducciones. Así pretendemos mostrar cómo el discurso ideológico que se esconde detrás del texto origen sobre la posición y el papel de la mujer en la sociedad ha sido importado y adaptado a la ideología de la España franquista y qué cambios significativos ha sufrido este mismo discurso en la segunda traducción analizada, publicada medio siglo después y treinta años desde el final del régimen franquista y el comienzo de la etapa democrática en España.

\section{MOTS CLÉS/KEYWORDS/PALABRAS CLAVE}

ambivalence, études de genre, censure, littérature d'enfance et de jeunesse, traduction ambivalence, gender studies, censorship, literature for children, translation ambivalencia, estudios de género, censura, literatura infantil y juvenil, traducción

\section{Introduction}

The present study focuses on two Spanish translations of Louisa May Alcott's bestknown novel, Little Women ${ }^{1}$ (1868-1869). ${ }^{2}$ Our main objective is to determine what images of women these translations have contributed to Spanish culture and how they have been consolidated in the collective imagination. Both published under the title Mujercitas, they belong to two different epochs: the first, ${ }^{3}$ by Molino Publishing House, was published in 1948, less than a decade after the end of the Spanish Civil War and during Franco's regime. The second, published by Lumen in 2004, is presented as the first "versión íntegra" in Spanish and was carried out by Gloria Méndez. ${ }^{4}$

Mujercitas is particularly interesting due to the large number of translations and adaptations published in Spanish and its intricate reception, which is characterised by anonymous translations, indirect translations, (at times) intentional confusion 
between adaptation and translation, ambiguous transfer of translation copyright and various forms of censorship (Hernández Socas and Giugliano 2019). All these factors led Méndez to claim, in the prologue to her translation, that "no es cierto que conozcamos de verdad esta novela" since the existing versions are nothing but "adaptaciones acarameladas y censuradas del texto que circularon durante años como única opción de lectura" (Méndez 2004: 7). These comments hint at the process of manipulation and simplification that the image of womanhood underwent in the translations prior to 2004. In the source text (ST) the image of womanhood prompts a variety of complex interpretations based on a number of contradictory features, which highlight the ambivalent interpretation of women in the novel (Fetterley 1979; Alberghene and Lyon Clark 1999: xxxi, among many others).

In this article we describe a number of stylistic and linguistic devices that generate this ambivalent image in the ST and investigate how and to what extent the censorship applied to translations during Franco's regime has modified this image. Moreover, by comparing the first translation, during the Francoist period, with the 2004 version, we hope to describe how the complexity of the ST has been rendered in the twenty-first century and to what degree these translation solutions can be telling of current ideological perspectives on women.

To make the reading of the article more agile, we have introduced the following abbreviations:

- Source Text: ST

- Target Text: TT

- 1868-1869/2005 edition of Little Women: ST1

- 1880/2017 edition of Little Women: ST2

- 1880/1948 edition of Mujercitas: TT1

- 1868-1869/2004 edition of Mujercitas: TT2

\section{Literature for Children, Gender Studies and Translation}

\subsection{Translating ambivalence in literature for children}

Within Translation Studies, the subsystem of Literature for Children has proven to be an ideal field for research on issues related to censorship and manipulation. According to Shavit (1986/2009: 112) and Fernández López (2000: 232), the peripheral position of literary translation in a target culture and, in addition to this, the little renown enjoyed by Literature for Children within a culture's literary canon contribute to explaining the "liberties" taken by translators during the translation of these kinds of texts. Furthermore, other factors that specifically belong to Literature for Children bolster these translation trends, such as the specific expectations that a certain culture shares in a given time about the typical textual features of a literary work for children; its pedagogical, didactic and moral aims, which may lead, at times, to an overprotection of infancy; the need to adapt the book to children's abilities, their world-knowledge and their linguistic and cognitive development (Shavit 1986/2009: 112-115; Oittinen 2000: 73-158; Desmidt 2006: 86; Sánchez Ortiz 2016: 13). All these factors lead to a "collision of norms" (Desmidt 2006: 87) since in the TT we observe a coming together and, at times, a clashing of norms between the target culture and the source culture (such as literary, social, commercial and profes- 
sional norms), to which translation is always subject, and norms specifically belonging to the subsystem of Literature for Children.

In the case of Alcott's novel, the very existence of two slightly different versions of the ST, the ambiguities related to the authorship of the first translations into Spanish and their censorship under Franco's fascist regime make it possible to hypothesise that the main features of the image of womanhood in the TT may have undergone severe changes.

Another element that adds complexity to our analysis is the phenomenon of ambivalence which characterises most literary works for children. With this term we refer to a number of linguistic and extra-linguistic strategies aimed at creating a text that addresses both young and adult readers (Shavit 1986/2009: 63-92; Oittinen 2000: 64; Alvstad 2008; O'Sullivan 2013: 452). Ambivalence represents one of the major translation challenges of Literature for Children, since most translations tend to simplify the rich complexity of the phenomenon or sacrifice it altogether in favour of just one of the possible interpretations, often the one that addresses its young readers.

\subsection{The image of womanhood in Gender Studies}

In the field of gender theories, the term woman, like that of man, identifies a social gender, that is to say, a discursive, socio-cultural and psychological construct that does not represent a fixed reality, but is rather manifold and may vary according to the time and place in which it is observed (Wodak 1997: 4). Gender as a discursive construct is partly determined by language, ${ }^{5}$ whereas as a social construct it is influenced by the socio-cultural context in which it develops. In this social environment, gender can be determined by attributing to it a number of stereotypes based on "naturalized norms and expectations about verbal behaviour [that] are imposed upon people" (Talbot 2003: 468), which are, in turn, linked to other parameters such as ethnic group, class, age and culture. Nevertheless, the theoretical work carried out by Judith Butler (1990) at the end of the 1980s and her theory of performativity allows for the possibility that the individual is not just a passive receptor of gender attributions, but may also proactively and dynamically determine it through his/her own words. ${ }^{6}$

Studying the image of womanhood in literary fiction means, therefore, recognising the features that authors use to evoke this social construct in their own work. The attribution of a social gender does not necessarily coincide with a biological gender. In our study, for example, social and biological genders coincide in the description of the image of womanhood embodied by the characters of Jo (Josephine March) and Marmee (Mrs. March). However, we will also make reference to the narrator of the novel, whose gender attribution may be ambiguous, especially in translation. In Little Women, the contradictory features that characterise the image of women have often been commented upon (Fetterly 1979: 370-371; Estes and Lant 1989: 121; Murphy 1990: 566). Our hypothesis is that this ambivalence in the text represents the figurative place where Alcott's writing turns into a performative text. By addressing a plural readership composed of both children and adults, the novel's ambivalence achieves the status of "interlocutory space" (Parker and Kosofsky Sedgwick 1995: 13) in which the subject is allowed to question and modify gender stereotypes. 
In Translation Studies, issues regarding gender have been tackled from different points of view (Simon 1996; von Flotow 2001, 2011), even though most of the scientific production still focuses on feminist discourse. In our study, we aim to describe the relationship between the translational and gender perspectives by taking into account the linguistic-stylistic solutions used to translate the most prominent features of the image of womanhood as a social construct in the novel, the social expectations that may have determined these choices in the target culture at two different historical moments and their ideological background.

Thus, by adopting a translational perspective and by carrying out a contrastive textual analysis, we aim to identify the linguistic framework that constitutes the discursive construction of womanhood and the elements which are manipulated in order to adapt the gender discourse imported from the United States into the target culture.

\subsection{Methodological notes}

Two studies on censorship and manipulation in the Spanish and French translations of Alcott's novel (Le Brun 2003; Llompart Pons 2016) have already tackled the problem of the image of womanhood in translation, but are distorted, in our opinion, by a methodological error. Llompart Pons mentions the two versions of the ST and observes that:

Alcott's original is already a case of authorial and editorial censorship, to which translations published during Franco's regime brought even more alterations. [...] Early Spanish translations of Little Women are, therefore, censored translations of an already censored text. (Llompart Pons 2016: 62)

We understand, therefore, that the translations carried out in Francoist times used the 1880 version $^{7}$ as their ST whereas Méndez's “integral version” is a translation of the 1868-1869 text. Nonetheless, in her analysis Llompart Pons compares both the 1948 and the 2004 translations with a single ST (Alcott 1868-1869/2005), which corresponds to the 1868-1869 edition (Showalter 2005: 1079). Llompart Pons's article falls here into a methodological error since her analysis should consist of two different comparisons: one between ST2 (1880) and its 1948 Spanish translation (TT1), and a second between ST1 (1868-1869) and its 2004 translation (TT2). Evidence of this mistake is given by the fourth instance of censorship regarding unconventional gender roles (Llompart Pons 2016: 67) in which the apparent shift in the 1948 translation is not an example of censorship, but rather a literal translation of the 1880 ST. $^{8}$

The same methodological doubt seems to be applicable to Le Brun's study (2003), in which seven French translations and adaptations of Little Women are compared with a single ST without any mention of the differences between the two STs. To avoid this methodological error we will carry out a contrastive analysis of both STs with their translations (the 1868 ST [= ST1] with the 2004 translation [= TT2], and the 1880 ST [= ST2] with the 1948 translation [= TT1]) to identify the different translation strategies adopted for the representation of womanhood.

Over the years, numerous classifications of translation techniques and strategies have been proposed, which cannot be summarized here. ${ }^{9}$ In our study we apply the classical three techniques of adjustment proposed by Nida (1964: 226-240) (additions, subtractions and alterations). Nida enumerates a detailed typology for each of these 
techniques. Since the focus of our study is not on translation techniques, we will not consider them here in details (see Molina and Hurtado Albir 2002). While the first two categories (addition and subtraction) are intuitively clear, alterations may present some interpretation problems. We have interpreted alterations as any kind of modification that implies a change of perspective in the TT compared to the ST.

\section{Contrastive textual analysis}

\subsection{The image of womanhood in Little Women}

Drawing on the numerous critical studies already published on Alcott's novel, ${ }^{10}$ we will describe the main features of the image of womanhood in ST1 and the changes introduced in ST2. Moreover, we will select the linguistic elements that characterise this image in the STs and will compare them with the translation solutions used in both TTs. Finally, we will link these elements to the target socio-cultural context.

The image of the middle class North American woman in Alcott's novel has been approached from different theoretical perspectives, such as the historicist, the biographical, the deconstructivist as well as the queer and gender perspectives. The most frequently stressed feature of this image concerns its ambivalence and the dichotomies that it produces (Fetterly 1979: 370-371; Estes and Lant 1989: 121; Murphy 1990: 566). As Murphy (1990: 565) argues, for example, women may appear as both "an alternative model of power and creativity," like the unconventional Jo (Josephine) and the ideal of "female patience, perseverance, good nature and industry," a being that voluntarily confines herself to the mere domestic environment, that represses herself and other members of her gender (her daughters, nieces and pupils) in order to abide by the norms of a patriarchal culture that justify her role in society only as a wife, a mother and the angel of the house (Grasso 1998: 183). The character of Beth, for example, would embody the ideal woman in patriarchal culture, who significantly succumbs to it and dies.

The title of the novel summarizes this ambivalence without resolving it. The adjective little actually refers to the fact that the main female characters already possess, or are striving to have, those qualities that make them women, despite their young age. What these qualities are, however, remains controverted, as we shall see.

The characters in the novel are portrayed gradually, that is, their distinguishing psycho-physical features are presented and reiterated at different moments in the narrative, even though descriptive passages are more frequent especially in the first part of the novel until approximately chapter VIII. Readers are able to envision the protagonists through the other characters' comments, through the depicted character's own words and through the description of the extradiegetic narrator, who seems to confer an authorial seal of objectivity on the portrayed features.

The characters that best represent the ambivalence of women, which we mentioned above, are Jo and Marmee. The first is a young woman whose ambition is to become an independent writer, rejecting the conventions of the white heterosexual society to which she belongs. She ends up, however, getting married in the second part of the book and giving up her dreams of writing. Her marriage symbolises her acceptance of traditional socio-cultural and ideological structures, even though she slightly diverts from them by marrying a foreigner who is also much older than her. 
As critical studies have pointed out, ST2 attenuates or effaces a number of masculine or unconventional features of this character (Showalter 2005).

As for Marmee, she is a central character in defining the image of womanhood for several reasons. Because of her husband's absence, Mrs. March presides over her house and symbolises the private feminine dimension of society, defined in opposition to, or at least as being separated from, the public, political, masculine dimension (for a problematization of the dichotomy public-private see Yuval-Davis 1997: 78-82). In chapter VIII, while talking to Jo, she admits that she had also been impatient and impulsive in her youth and that these features of her personality still cause her problems. These words make it possible to interpret Marmee as an adult, a riper version of Jo. The ambivalence of her portrayal can be seen in this description and at many other moments, of which we will mention but a few. Her liberal facet can be surmised, for example, in the scenes in which Mrs. March reads passages from well-known female progressive authors (for example Frederika Bremer and Maria Edgeworth) to her daughters, in her preoccupation for the living conditions of the poor and her criticism of the accumulation of wealth for its own sake. However, on many other occasions, Marmee encourages her daughters to accept the values of the patriarchal society of the time and to suppress their instincts and impulses.

The ambivalence of the image of womanhood can also be observed in the narrator. Readers of the ST tend to identify the narrator with a woman, mainly because the novel's author is a woman. The narrator's voice is, in fact, often interpreted as Alcott's own voice and as reflecting her point of view, even though expert readers are aware of its fictional nature and of the possibility of attributing the narrator both the female and the male gender. We argue that the extradiegetic and omniscient narrator of the novel greatly contributes to the definition of the ambivalence of the female characters in Little Women, since the narrator's comments seem to endorse the traditional moral and symbolic values that can be evinced from the events of the story, but they also represent, at other times, a criticism of certain social patriarchal conventions that stifle women's creative aspirations. Despite this, the narrator's voice should not be considered neutral, anachronic, nor taken out of its ideological positioning, which is the white, heterosexual, Christian ideology of middle-class New England in the second half of the nineteenth century. The narrator's voice is particularly relevant to our analysis due to the interaction of the linguistic and extralinguistic features that define it. Our hypothesis is that the interplay that defines the feminine features of this voice is subtler than those defining the voice of the female characters in the novel. As a consequence, this voice becomes the place where manipulation can occur more easily, and slyly, during the translation process, in which other viewpoints (for instance, the translator's and the editor's) also intrude in addition to that of the author.

As a consequence, our analysis will focus on the following aspects: (1) the image of Jo and Marmee as conveyed from the point of view of other characters, of themselves and in relationship with other female characters in the novel; (2) the image of Jo and Marmee as described by the narrator; (3) the image of the narrator, as inferred from his/her own words. Point (3) is particularly relevant if we keep in mind that any reader's interpretation of the narrator's image depends exclusively on what can be inferred from the narrator's own words. 


\subsection{Two emblematic translations}

A number of reasons justify the selection of these two translations, among the many versions of the novel in Spanish. ${ }^{11}$ We will start by describing the motives behind the choice of the 1948 translation (3.2.1.) and, in Section 3.2.3., we will justify our choice of the 2004 translation.

In both versions the title is Mujercitas. The use of a synthetic diminutive formed by a morpheme, such as the suffix (-itas) to the word mujer (woman), introduces connotations of fragility, defenselessness and infantilization, as we shall explain. ${ }^{12}$ The choice of the same title for both the 1948 and the 2004 versions is a consequence, in our opinion, of the fact that by the time Méndez published her translation, Mujercitas had become the established title for this classic book for children in Spain.

\subsubsection{The first translation (1948): institutional censorship and self-censorship}

Mujercitas, published by Molino in 1948 and later ceded to other publishers, was the first translation in the Spanish market, and was in print until at least 2014 (Edimat from 1999 to 2014; RBA from 2004 to 2010; Mare Nostrum in 2010). Despite its great number of re-editions, the translator's name has never been explicitly mentioned in the book even though, starting with the 1958 edition, we find a reference to him or her under the initials E.M. The acronym, however, most probably indicates the publishing house (Ediciones Molino). By comparing the 1943 translation of the novel published by Molino in Argentina, translated by Enriqueta S. Albanella, with the 1948 Spanish edition, we discover that we are actually dealing with the same text, despite a few changes in the lexical choice (Hernández Socas and Giugliano 2019). The translation is emblematic not only for its intricate reception in Spain but also for the gender censorship that it endured, as already highlighted by Llompart Pons (2016), so that the image of womanhood presented in the TT is very different from that of the ST.

According to Fernández López (2007), the first translations of Mujercitas in Spain were subjected to two different kinds of censorship: Francoist institutional censorship and the self-censorship that publishers and translators exerted beforehand on the text in order to avoid having their translations blocked by the state censor when they were ready to be printed. As for the first kind of censorship, Fernández López (2007: 42) found in the Archivo General de la Administración (AGA) in Madrid files and comments dated between 1940 and 1955, in which we find references to (a) a translation of Mujercitas that was banned from 1940 to 1949; (b) two translations that were accepted after overcoming the censorial process, and (c) a censored version between 1950 and 1955. Moreover, according to Fernández López ${ }^{13}$ the last censored version (c) is actually the translation that Molino published in Argentina in 1943, carried out by Albanella. This version, as we have already mentioned, was brought to Spain in 1948 without any indication of its translator and later overcame the censorial filter. In her concluding remark on these instances of institutional censorship, Fernández López observes how chaos and a lack of clarity seemed to completely dominate the stories behind these translations, since it is not clear at all, at least from the files, which texts were censored and what the ultimate motives adduced by the censor were. However, a number of censorial recommendations indicated that several religious allusions in the translation should be changed, especially in view of the young Spanish readership 
of the novel (Fernández López 2007: 36). This obscure story of institutional censorship seems to fully justify the selection of the 1948 translation as our first case study.

As for self-censorship, one would probably not think of finding it in Mujercitas, considering that most of the values and virtues exalted in the ST as desirable in women partially correspond to the image of the ideal woman as advertised under Franco (Martens, Soto Vázquez, et al. 2016: 43). The image of women as faithful wives, dedicated mothers and obedient daughters becomes the embodiment of national moral values like self-sacrifice, obedience, abnegation and subordination. These values coincide with those promoted in Spain by the Sección Femenina, whose function consisted of the diffusion and preservation within Spanish society of an image of womanhood as the angel of the house and champion of traditional values, those very values that also kept her away from the country's public political life (Manrique Arribas 2003: 85-90; Heritier 2008: 127-132). We may hypothesise, therefore, that any form of self-censorship applied to the image of women in the translations of this period will tend to heighten the features of the image that coincide with the dominant values of both source and target context and will attenuate those others that collide with them, which can often be found in the characters of Jo and Marmee.

\subsubsection{The image of womanhood in TT1 (1948)}

Among the main translation strategies that affect the image of womanhood in TT1, we have identified total or partial subtractions, additions of elements often denoting values that could not be found in the original as well as alterations that attenuate or stress specific features of womanhood. The use of diminutives for the description of the physical appearance of the female characters seems particularly significant. Diminutive suffixes in Spanish are not only used to indicate the reduced dimension of an object or a person, but they may also evoke subjective value judgements (Veidenberga 2014: 175). As stated in the Nueva gramática de la lengua española, ${ }^{14}$ the diminutive suffixes may have both an attenuating and an intensifying stylistic function and are charged with connotations. What seems particularly significant in TT1 is that these appreciative diminutives are not employed uniformly for all characters in the novel. They are mostly introduced anew in those parts of the text that concern the physical description of the March sisters, even though they are virtually absent in the description of Jo, with the exception of a number of instances that we will discuss later on. These diminutives, often related to notions like fragility, physical weakness, tenderness, passivity, can be considered part of a strategy aimed at heightening the traditional image of women and their role in society. As de Beauvoir observed when she referred to Little Women,

$[\mathrm{t}]$ o be feminine is to appear weak, futile, docile. The Young girl is supposed not only to deck herself out, to make herself ready, but also to repress her spontaneity and replace it with the studied grace and charm taught her by her elders. Any self-assertion will diminish her femininity and her attractiveness. (de Beauvoir 1949/1953: 359)

Here are some examples: 
Diminutives

\begin{tabular}{|c|c|c|c|}
\hline & ST2 (Alcott 1880/2017) & $\begin{array}{c}\text { TT1 (Alcott } 1880 / 1948, \text { translated } \\
\text { by Albanella) }\end{array}$ & Strategy \\
\hline 1) & And Meg shook her head [...]. (p. 3) & $\begin{array}{l}\text { Al decir esto sacudió pesarosa su } \\
\text { cabecita, [...]. (p. } 8)\end{array}$ & Alteration \\
\hline 2) & $\begin{array}{l}\text { And Beth looked at her rough hands } \\
\text { with a sigh }[\ldots] . \text { (p. } 3 \text { ) }\end{array}$ & $\begin{array}{l}\text { Y Beth dirigió una mirada a sus } \\
\text { manitas enrojecidas }[\ldots] \text { (p. } 9 \text { ) }\end{array}$ & Alteration \\
\hline 3) & $\begin{array}{l}{[\ldots] \text { and no one contradicted her, for }} \\
\text { the 'Mouse' was the pet of the family. } \\
\text { (p. 6) }\end{array}$ & $\begin{array}{l}{[\ldots] \text { y nadie la contradijo porque la }} \\
\text { "ratita" era el ídolo de la familia. } \\
\text { (p. 10) }\end{array}$ & Alteration \\
\hline 4) & $\begin{array}{l}\text { Elizabeth, or Beth, as everyone called } \\
\text { her, was a rosy, smooth-haired, } \\
\text { bright-eyed girl of thirteen [...]. (p. 8) }\end{array}$ & $\begin{array}{l}\text { En cuanto a Elisabeth o Beth era una } \\
\text { niña de trece años, de carita rosada, } \\
\text { pelo liso y ojos claros [...]. (p. 11) }\end{array}$ & Addition \\
\hline 5) & $\begin{array}{l}\text { Amy, though the youngest, was a most } \\
\text { important person, in her own opinion } \\
\text { at least. (p. 8) }\end{array}$ & $\begin{array}{l}\text { Amy, la más joven, era, según su } \\
\text { propia opinión, una personita } \\
\text { importante. (p. 11) }\end{array}$ & Alteration \\
\hline 6) & $\begin{array}{l}\text { Mrs. March glanced at Meg, who was } \\
\text { looking very pretty in her gingham } \\
\text { morning gown }^{(a)} \text {, with the little curls }{ }^{(b)} \\
\text { blowing about her forehead, and very } \\
\text { womanly, as she sat sewing at her little } \\
\text { worktable }^{(\mathrm{c})} \text {, full of tidy white rolls, so } \\
\text { unconscious of the thought in her } \\
\text { mother's mind as she sewed and sang, } \\
\text { while her fingers flew and her thoughts } \\
\text { were busied with girlish fancies }{ }^{(\mathrm{d})} \text { as } \\
\text { innocent and fresh as the pansies in her } \\
\text { belt, that Mrs. March smiled and was } \\
\text { satisfied. (p. 212) }\end{array}$ & $\begin{array}{l}\text { La señora March miró a Meg, que } \\
\text { estaba muy linda con su batita }{ }^{(\mathrm{a})} \text { de } \\
\text { mañana y los ricitos }{ }^{(\mathrm{b})} \text { que } \\
\text { encuadraban su frente y que } \\
\text { aparecía muy femenina sentada ante } \\
\text { su costurerito } \text { o }^{(\mathrm{c})} \text {, lleno de pequeños } \\
\text { rollos blancos. Inconsciente de lo } \\
\text { que su madre pensaba, Meg cosía y } \\
\text { cantaba, y volaban sus dedos, } \\
\text { mientras entretenía su imaginación } \\
\text { en pensamientos tan puros }{ }^{(\mathrm{d})} \text { e } \\
\text { inocentes y tan lozanos como las } \\
\text { flores que llevaba en su cintura. } \\
\text { (p. 126) }\end{array}$ & $\begin{array}{l}\text { (a) Addition } \\
\text { (b) No change } \\
\text { (c) No change } \\
\text { (d) Alteration }\end{array}$ \\
\hline
\end{tabular}

In TT1 the use of diminutives seems to abound especially in the narrator's descriptions. The introduction of these elements produces a stylistic change that affects the way the narrator's image may be perceived as it confers upon him/her a certain patronizing attitude towards the March sisters. The use of diminutives that characterise the narrator's descriptions of Meg, Beth and Amy in TT1 infantilises the characters and, at the same time, connotes the narrator's attitude as condescending towards them. In example 6, apart from the addition of the diminutive batita (little gown) to the two diminutives already present in the ST (little curls and little worktable), we can also observe the modulation of the adjective girlish, translated as puros (pure), which reveals the translator's unambiguous moral interpretation of the text and erases the original ambivalence. As for Jo, in the ST, the narrator defines this character in opposition to her sisters' femininity by using adjectives such as gentlemanly, unladylike, unmanly. In the translation, Jo's masculine features are attenuated by omitting these adjectives or by substituting them with others that are less directly associated with the notion of masculinity. These changes in TT1 downplay the flippant (and militant) personality of the character, as we can see in the examples below: 
TABLE 2

Masculine features

\begin{tabular}{|c|c|c|c|}
\hline & ST2 (Alcott 1880/2017) & $\begin{array}{c}\text { TT1 (Alcott 1880/1948, translated by } \\
\text { Albanella) }\end{array}$ & Strategy \\
\hline 7) & $\begin{array}{l}\text { cried Jo, examining the heels of her } \\
\text { shoes in a gentlemanly manner. (p. } 3 \text { ) }\end{array}$ & $\begin{array}{l}\text { - exclamó Jo examinando los tacones } \\
\text { de sus botas. (p. } 8 \text { ) }\end{array}$ & Subtraction \\
\hline 8) & $\begin{array}{l}\text { - 'Don't, Jo. It's so boyish!' } \\
\text { - 'That's why I do it.' } \\
\text { - 'I detest rude, unladylike girls!' } \\
\text { - 'I hate affected, niminy-piminy } \\
\text { chits!' (p. 3) }\end{array}$ & $\begin{array}{l}\text { - ¡No hagas eso, Jo, es cosa de chicos! } \\
\text { - Por eso lo hago. } \\
\text { - Detesto las muchachas de modales } \\
\text { ordinarios. } \\
\text { - Y yo detesto las cursiladas de las que } \\
\text { se creen señoritas elegantes. (p. } 9 \text { ) }\end{array}$ & Alteration \\
\hline 9) & $\begin{array}{l}\text { Jo wanted to lay her head down on } \\
\text { that motherly bosom, and cry her grief } \\
\text { and anger all away, but tears were an } \\
\text { unmanly weakness [...]. (p. 132) }\end{array}$ & $\begin{array}{l}\text { Jo hubiera querido apoyar su cabeza } \\
\text { en el pecho de su madre y llorar allí } \\
\text { hasta que desaparecieran su pena y su } \\
\text { enfado, pero las lágrimas eran signo } \\
\text { de debilidad [...]. (p. } 81 \text { ) }\end{array}$ & Subtraction \\
\hline 10) & $\begin{array}{l}\text { [...] Jo in maroon, with a stiff, } \\
\text { gentlemanly linen collar, and a white } \\
\text { chrysanthemum or two for her only } \\
\text { ornament. (p. } 43 \text { ) }\end{array}$ & $\begin{array}{l}{[\ldots] \text { castaño el de Jo, con cuello blanco }} \\
\text { muy tieso de hilo y, por todo adorno, } \\
\text { uno o dos crisantemos blancos. (p. } 31 \text { ) }\end{array}$ & Subtraction \\
\hline
\end{tabular}

In examples 7, 9 and 10, any reference to Jo's masculinity is erased in TT1, whereas in example 8 the adjective unladylike has been rendered with de modales ordinarios (of vulgar manners), which also omits any reference to gender. These omissions produce a less ambivalent image of Jo, whose masculine attitude is downsized. In the first chapter of the novel, in which the narrator describes the four sisters, a similar translation strategy is adopted, resulting in a partial adaptation of Jo's body to the target culture's standards of beauty. In accordance with the traditional sweetened, passive image of women, devoid of any masculine features, described above, TT1 strips Jo's character of her clumsiness and rebelliousness (example 11). The translator achieves this effect by translating thin with esbelta, which adds connotations of altura (physical height) y de figura proporcionada (proportioned figure) (RAEASALE 2018) ${ }^{15}$ (example 11a), eliminating the metaphorical comparison with a colt and the reference to the lack of proportion in Jo's limbs (example 11b-c) and by omitting the translation of the adjective comical (example 11d).

TABLE 3

Clumsiness

\begin{tabular}{|c|c|c|c|}
\hline & ST2 (Alcott 1880/2017) & $\begin{array}{c}\text { TT1 (Alcott 1880/1948, translated by } \\
\text { Albanella) }\end{array}$ & Strategy \\
\hline 11) & $\begin{array}{l}\text { Fifteen-year-old Jo was very tall, } \\
\text { thin }^{(a)} \text {, and brown, and reminded } \\
\text { one of a colt }^{(b)} \text {, for she never } \\
\text { seemed to know what to do with } \\
\text { her long limbs, which were very } \\
\text { much in her way }{ }^{(c)} \text {. She had a } \\
\text { decided mouth, a comical nose, } \\
\text { and sharp }{ }^{(d)} \text {, gray eyes, which } \\
\text { appeared to see everything, and } \\
\text { were by turns fierce, funny, or } \\
\text { thoughtful. (p. } 7)\end{array}$ & $\begin{array}{l}\text { Jo tenía quince años y era muy alta, } \\
\text { esbelta y morena. La boca de expresión } \\
\text { resuelta, la nariz un tanto respingona, } \\
\text { los ojos grises muy penetrantes, ojos } \\
\text { que parecían verlo todo y que unas } \\
\text { veces tenían expresión de enojo, otras } \\
\text { de alegría y otras se tornaban graves y } \\
\text { pensativos. Tenía las espaldas } \\
\text { redondas, las manos y los pies grandes } \\
\text { y la tosquedad de una chica que va } \\
\text { haciéndose mujer a pesar suyo. (p. } 11)\end{array}$ & $\begin{array}{l}\text { (a) Alteration } \\
\text { (b) Subtraction } \\
\text { (c) Subtraction } \\
\text { (d) Alteration }\end{array}$ \\
\hline
\end{tabular}


As for the presence of diminutives applied to Jo in TT1, we seem to find them in very specific situations as a way of compensating the rebellious nature of the character, as we can see in example 12:

TABLE 4

Diminutives applied to Jo

\begin{tabular}{|c|c|c|c|}
\hline & ST2 (Alcott 1880/2017) & $\begin{array}{c}\text { TT1 (Alcott } 1880 / 1948, \text { translated by } \\
\text { Albanella) }\end{array}$ & Strategy \\
\hline 12) & $\begin{array}{l}\text { Although the oldest, Jo had the } \\
\text { least self-control, and had hard } \\
\text { times trying to curb the fiery } \\
\text { spirit }^{(a)} \text { which was continually } \\
\text { getting her into trouble. [...] Poor }^{(\mathrm{b})} \\
\text { Jo tried desperately }{ }^{(\mathrm{c})} \text { to be good } \\
\text { [...]. (p. 128) }\end{array}$ & $\begin{array}{l}\text { A pesar de ser la mayor, Jo tenía muy } \\
\text { poco dominio sobre sí misma, y pasaba } \\
\text { malos ratos tratando de vencer aquel } \\
\text { genio suyo que, continuamente, le } \\
\text { estaba dando disgustos. [...] Trataba, } \\
\text { en efecto, la pobrecilla de ser buena, } \\
{[\ldots] \text { ( } \text { (p. } 77 \text { ) }}\end{array}$ & $\begin{array}{l}\text { (a) Alteration } \\
\text { (b) Alteration } \\
\text { (c) Subtraction }\end{array}$ \\
\hline
\end{tabular}

Examples 12 refers to a scene in chapter VIII that describes Jo's inner fight against her own combative and impatient character in favour of a more condescending, restrained attitude. The fragment is particularly relevant for the ambivalent reading of Jo. In TT1, the use of the diminutive pobrecilla (little poor + feminine ending) and the omission of the adjective fiery and the adverb desperately contribute to rounding the edges of her personality.

As for the translation of the segments describing Marmee, we find slight changes and displacements of adjectives, which, however, do not seem to seriously alter the image of this female character in TT1.

In the ST, the four sisters always use either the term Mother or, above all, the nickname Marmee, which they themselves affectionately coined, whereas the narrator mostly uses the form Mrs. March. The ST's readers, especially those coming from New England, would easily recognise in the nickname a variation of the name mommy. ${ }^{16}$ In TT1, the translator uses similar familiar forms such as mamá, mamita and mamaíta. A number of alterations affect the very first description of Marmee made by the narrator, as we can see in example 13:

\section{TABLE 5}

Marmee

\begin{tabular}{|c|c|c|c|}
\hline & ST2 (Alcott 1880/2017) & $\begin{array}{c}\text { TT1 (Alcott 1880/1948, translated by } \\
\text { Albanella) }\end{array}$ & Strategy \\
\hline 13) & $\begin{array}{l}\text { 'Glad to find you so merry, my } \\
\text { girls,' said a cheery voice at the } \\
\text { door, and actors and audience } \\
\text { turned to welcome a tall(a), } \\
\text { motherly lady with a 'can I help } \\
\text { you' look }^{(\mathrm{b})} \text { about her which was } \\
\text { truly delightful }{ }^{(\mathrm{b})} \text {. She was not } \\
\text { elegantly dressed, but a noble- } \\
\text { looking woman } \\
\text { thought the gray cloak and } \\
\text { unfashionable bonnet covered the } \\
\text { most splendid mother }{ }^{(\mathrm{d})} \text { in the } \\
\text { world. (p. 12) }\end{array}$ & $\begin{array}{l}\text { - Me alegra mucho encontraros tan } \\
\text { divertidas, hijas mías - dijo una voz } \\
\text { agradable desde la puerta y al oírla, } \\
\text { actores y espectadores corrieron a dar la } \\
\text { bienvenida a una señora de porte } \\
\text { distinguido y aspecto maternal, cuyo } \\
\text { rostro tenía una expresión amable y } \\
\text { seductora. A pesar de no ir ataviada } \\
\text { elegantemente, las cuatro niñas la } \\
\text { consideraban la persona más } \\
\text { encantadora del mundo, con su raído } \\
\text { abrigo gris y su sombrero pasado de } \\
\text { moda. (p. 13-14) }\end{array}$ & $\begin{array}{l}\text { (a) Alteration } \\
\text { (b) Alteration } \\
\text { (c) Subtraction } \\
\text { (d) Alteration }\end{array}$ \\
\hline
\end{tabular}


In the ST, Mrs. March is described as tall, whereas in TT1 we find the expression de porte distinguido (of distinguished bearing) that evokes a certain natural elegance of her figure, despite the lack of elegance of her clothes, which is mentioned shortly afterwards. In addition to this, the adjective seductora stresses her beauty as a woman and emphasises her femininity, even though this quality is combined with her maternal friendly attitude (aspecto maternal, una expresión amable). As we will show later, there exists a significant difference between the ST2 (1880) and its previous version (ST1, 1868), since in ST1 the image of Mrs. March is less elegant and refined in her demeanour. This difference does not affect, however, the analysis of TT1, which seems to reproduce an image of a mother and woman similar to ST2.

\subsubsection{TT2: the first "integral" version of Little Women in Spanish}

The 2004 translation of Little Women, by Gloria Méndez, is the latest version to appear in the Spanish publishing market. Since then it has been reissued several times (2006 and 2010 by Debolsillo, 2014 by Lumen, and 2015 by Penguin Clásicos). In these editions we find a preface written by the translator in which she stresses the novelty of her work, which is allegedly the first, integral and uncensored translation of the novel into Spanish, as well as being based on the very first edition of the book, published in 1868-1869, and not on the one modified and "sweetened" by North American publishers and by Alcott herself in 1880 (Méndez 2004: 8). ${ }^{17}$ Méndez's translation, therefore, neither suffered institutional censorship in Spain nor the changes introduced by Alcott's editors. Our objective is to understand and describe the relationship that can be established between the way Méndez tackles the ambivalence of the image of womanhood in her translation and the new contextual conditions in which the translation was done. Finally, we also attempt to clarify, albeit briefly, the relationship between the translation solutions adopted and the ideology behind them.

\subsubsection{The image of womanhood in TT2 (2004)}

In order to describe the main features that characterise the image of women in TT2 we will adopt the same contrastive approach already used for the analysis of TT1. Indirectly, this study will also allow us to compare ST1 with ST2 and TT1 with TT2.

We will start by taking into account the description of the four sisters as found in the first chapter of the book (see also 3.2.2.), which underwent no changes from ST1. For economy of space, and to avoid redundancies, we will consider only three examples:

Table 6

Description of the sisters

\begin{tabular}{|c|l|l|l|}
\hline \multicolumn{1}{|c|}{ ST1 (Alcott 1868-1869/2005) } & \multicolumn{1}{|c|}{$\begin{array}{c}\text { TT2 (Alcott 1868-1869/2004, translated } \\
\text { by Méndez) }\end{array}$} & Strategy \\
\hline $\begin{array}{l}\text { 'You're a dear, and nothing else,' } \\
\text { answered Meg warmly, and no } \\
\text { one contradicted her, for the } \\
\text { 'Mouse' was the pet of the family. } \\
\text { (p. 10) }\end{array}$ & $\begin{array}{l}\text { Tú eres un encanto, querida, ni más ni } \\
\text { menos - contestó Meg con cariño y nadie } \\
\text { la contradijo, porque todos adoraban a la } \\
\text { pequeña Beth, el ratoncito, la mascota de } \\
\text { la familia. (p. 17) }\end{array}$ & $\begin{array}{l}\text { Addition } \\
\text { Alteration }\end{array}$ \\
\hline
\end{tabular}




\begin{tabular}{|c|l|l|l|}
\hline 15) & $\begin{array}{l}\text { Margaret, the eldest of the four, } \\
\text { was sixteen, and very pretty, being } \\
\text { plump and fair, with large eyes, } \\
\text { plenty of soft brown hair, a sweet } \\
\text { mouth, and white hands, of which } \\
\text { she was rather vain. (p. 10) }\end{array}$ & $\begin{array}{l}\text { Margaret, la mayor de las cuatro, contaba } \\
\text { dieciséis años, era una joven muy hermosa, } \\
\text { rolliza, de piel clara y ojos grandes, con } \\
\text { una larga cabellera castaña, sonrisa dulce } \\
\text { y manos blanquísimas de las que estaba } \\
\text { muy orgullosa. (p. 18) }\end{array}$ & Alteration \\
\hline 16) & $\begin{array}{l}\text { Elizabeth --or Beth, as everyone } \\
\text { called her-- was a rosy, smooth- } \\
\text { haired, bright-eyed girl of } \\
\text { thirteen. (p. 10) }\end{array}$ & $\begin{array}{l}\text { Elizabeth --o Beth, como todos la } \\
\text { llamaban--, era una muchachita de trece } \\
\text { años, mejillas sonrosadas, cabello suave y } \\
\text { ojos vivos. (p. 18) }\end{array}$ & Alteration \\
\hline
\end{tabular}

Méndez produces a translation that is semantically close to ST2, even though she adds a number of small variations so as to gain idiomatic fluency (as in example 15): sonrisa dulce (sweet smile for sweet mouth), and con una larga cabellera castaña (with long brown hair for plenty of soft brown hair). The only diminutives that can be found in the fragments quoted above refer to the word ratoncito (little mouse) (example 14), which has connotations of endearment, and to muchachita (little girl) (example 16). Unlike TT1, no diminutives are introduced in the fragments quoted in 3.2.2, which cannot be presented here for economy of space. Let us now consider a scene in chapter XII in which the narrator describes Meg (and Mrs. March observing Meg):

TABLE 7

Diminutives

\begin{tabular}{|c|c|c|c|}
\hline & ST1 (Alcott 1868-1869/2005) & $\begin{array}{l}\text { TT2 (Alcott } 1868-1869 / 2004 \\
\text { translated by Méndez) }\end{array}$ & Strategy \\
\hline 17) & $\begin{array}{l}\text { Mrs. March glanced at Meg, who } \\
\text { was looking very pretty in her } \\
\text { gingham morning-gown, with the } \\
\text { little curls }{ }^{(a)} \text { blowing about her } \\
\text { forehead, and very womanly }{ }^{(b)} \text {, as } \\
\text { she sat sewing at her little } \\
\text { worktable }^{(c)} \text {, full of tidy white rolls; } \\
\text { so, unconscious of the thought in } \\
\text { her mother's mind, she sewed and } \\
\text { sang, while her fingers flew and her } \\
\text { mind was with girlish fancies }{ }^{(d)} \text { as } \\
\text { innocent and fresh as the pansies in } \\
\text { her belt, that Mrs. March smiled } \\
\text { and was satisfied. (p. 130) }\end{array}$ & $\begin{array}{l}\text { La señora March miró a Meg, que } \\
\text { estaba muy guapa con un sencillo } \\
\text { vestido de guinga. Los rizos le caían } \\
\text { sobre la frente y, sentada junto a un } \\
\text { costurero lleno de ordenados rollos } \\
\text { blancos, tenía un aspecto muy } \\
\text { femenino. Ajena a los pensamientos } \\
\text { de su madre, la joven cosía y cantaba; } \\
\text { sus dedos se movían con destreza y en } \\
\text { su mente bullían ilusiones juveniles, } \\
\text { tan frescas e inocentes como las flores } \\
\text { que decoraban su cinturón. La señora } \\
\text { March sonrió de satisfacción. (p. 192) }\end{array}$ & $\begin{array}{l}\text { (a) Subtraction } \\
\text { (b) No change } \\
\text { (c) Subtraction } \\
\text { (d) No change }\end{array}$ \\
\hline
\end{tabular}

If we compare ST2 (example 6) and ST1 above (example 17), we will observe some minor stylistic changes at the lexical level (thought instead of mind) and in the punctuation, which do not seem to modify the way the image is presented in both texts. Méndez chooses not to translate the analytical diminutives that can be found in ST1: Little curls/los rizos [the curls] and Little working table/Un costurero [a working table]. In ST1 these diminutives contribute to evoking an image of innocence and candour that is heightened in the text by an explicit similitude, "innocent and fresh as the pansies in her belt" (Alcott 1868-1869/2005: 130), and is indirectly suggested by a series of adjectives and nouns linked together through an isotopic chain. These terms belong to similar associative semantic fields, such as (a) tidy, white, unconscious, girlish, innocent, and fresh; (b) fancies, pansies, and (c) verbal expressions like blowing and flew, which suggest lightness. 
Moreover, these diminutives also introduce a different focalization of the character that suggests an affective position closer to Meg, so that the narrator seems to embrace Mrs. March's emotional point of view and adopt an affectionate silent regard similar to the one that the mother bestows on her daughter. In TT2 the omission of these diminutives and the translation of girlish fancies with ilusiones juveniles (youthful eagerness) lead to a certain emotional detachment from the character's description.

Let us now consider Jo's character, whose description in chapter I is provided by Jo's sisters and by the young woman's own words.

\section{Table 8}

Jo

\begin{tabular}{|c|c|c|c|}
\hline & ST1 (Alcott 1868-1869/2005) & $\begin{array}{c}\text { TT2 (Alcott } 1868-1869 / 2004 \text {, translated } \\
\text { by Méndez) }\end{array}$ & Strategy \\
\hline 18) & $\begin{array}{l}\text { "Jo does use such slang words } \text { s }^{(\mathrm{a})} \text {," } \\
\text { observed Amy, with a reproving } \\
\text { look at the long figure stretched } \\
\text { on the rug (b). Jo immediately sat } \\
\text { up, put her hands in her apron } \\
\text { pockets, and began to whistle. } \\
\text { "Don't, Jo; it's so boyish"." } \\
\text { "That's why I do it." } \\
\text { "I detest rude, unlady-like } \\
\text { girls }{ }^{(\mathrm{d})} \text {." } \\
\text { "I hate affected, niminy piminy } \\
\text { chits." (p. 9) }\end{array}$ & $\begin{array}{l}\text { - Jo dice muchas palabras vulgares } \\
\text {-observó Amy lanzando una mirada } \\
\text { reprobatoria a la joven, que seguía } \\
\text { tendida sobre la alfombra. Jo se } \\
\text { incorporó de inmediato, metió las manos } \\
\text { en los bolsillos y empezó a silbar - ¡No } \\
\text { hagas eso, Jo! ¡Pareces un chico! } \\
\text { - Precisamente por eso lo hago. } \\
\text { - ¡No soporto a las jovencitas } \\
\text { maleducadas y poco femeninas! } \\
\text { - Pues a mí me sacan de quicio las niñas } \\
\text { cursis y resabidas. (p. 16) }\end{array}$ & $\begin{array}{l}\text { (a) Alteration } \\
\text { (b) Alteration } \\
\text { (c) No change } \\
\text { (d) No change }\end{array}$ \\
\hline 19) & $\begin{array}{l}\text { "I hate to think I've got to grow } \\
\text { up and be Miss March, and wear } \\
\text { long gowns, and look as prim as } \\
\text { a China-aster }{ }^{(a)} \text {. It's bad enough } \\
\text { to be a girl, any-way, when I like } \\
\text { boys'(b) games, and work, and } \\
\text { manners. I can't get over my } \\
\text { disappointment in not being a } \\
\text { boy (c), and it's worse than ever } \\
\text { now, for I'm dying to go and fight } \\
\text { with papa, and I can only stay at } \\
\text { home and knit like a poky old } \\
\text { woman; [...]." (p. 9) }\end{array}$ & $\begin{array}{l}\text { Detesto tener que crecer, convertirme en } \\
\text { la señorita March, vestir de largo y ser } \\
\text { una remilgada. Ya me parece bastante } \\
\text { malo ser una chica cuando lo que me } \\
\text { gusta son los juegos, los trabajos y la } \\
\text { forma de comportarse de los muchachos. } \\
\text { Me parece una pena no haber nacido } \\
\text { hombre, sobre todo en momentos como } \\
\text { este, en el que preferiría acompañar a } \\
\text { papá y luchar a su lado en lugar de } \\
\text { quedarme en casa tejiendo como una } \\
\text { vieja. (p. 16-17) }\end{array}$ & $\begin{array}{l}\text { (a) Subtraction } \\
\text { (b) No change } \\
\text { (c) Alteration }\end{array}$ \\
\hline 20) & $\begin{array}{l}\text { "Poor Jo; it's too bad! But it can't } \\
\text { be helped, so you must try to be } \\
\text { contented with making your } \\
\text { name boyish, an playing brother } \\
\text { to us girls," [...]. (p. 9) }\end{array}$ & $\begin{array}{l}\text {-Pobre Jo, ¡qué mala suerte! Pero la cosa } \\
\text { no tiene remedio, de modo que tendrás } \\
\text { que conformarte con acortar tu nombre } \\
\text { para que suene más masculino y actuar } \\
\text { como si fueses nuestro hermano en lugar } \\
\text { de nuestra hermana- (p. 17) }\end{array}$ & Alteration \\
\hline 21) & $\begin{array}{l}\text { "If Jo is a tomboy and Amy a } \\
\text { goose, what am I, please?" (p. 9) }\end{array}$ & $\begin{array}{l}\text {-Si Jo es demasiado masculina y Amy } \\
\text { una niña cursi, ¿podrías decirme qué soy } \\
\text { yo, por favor? - (p. 17) }\end{array}$ & Alteration \\
\hline
\end{tabular}

In example 18 Amy criticises Jo for her boyish and unlady-like behaviour, which is rendered in Spanish as a behaviour similar to un chico or to girls who are poco femeninas. In TT2, moreover, this criticism is emphasised by translating the term slang words with palabras vulgares (vulgar words). In example 19 (a-c), Jo replies to Amy by stressing her frustration over the restrictive social norms that her condition 
as a woman imposes on her and by regretting "not being a boy" (Alcott 18681869/2005: 9). This sentence may be interpreted, as de Beauvoir does (1949/1953: 374-375), as the expression of girls and young women's longing for the social privileges attributed to boys and young men. In Méndez's translation small semantic changes are introduced that seem to slightly intensify Jo's masculinity, although Jo's attitude remains similar to the one represented in ST1.

In example 20, Meg's comment does not contradict Jo's words, thus confirming Jo's masculine features to readers and, at the same time, agreeing on the social advantages of being a boy at the time the story takes place. In the translation, both the term boyish and tomboy (example 21) are translated with the word masculino (masculine), which introduces a slight shift in TT2 towards a more formal neutral register. In English, in fact, the term boyish identifies not only a social gender but also an age range (that of a child or adolescent) and may imply immaturity. The term tomboy, on the other hand, makes references to a cultural concept and (to) a literary convention that was becoming more and more pervasive in the North American literary panorama in those years, one significantly consolidated by Alcott's Little Women (Abate 2008: 24-49). These connotations are not present in the Spanish translation. We observe, moreover, that masculino is often used in TT2 to translate a variety of terms that refer to Jo's masculinity, as seen in the following examples.

TABLE 9

Masculine features

\begin{tabular}{|l|l|l|l|}
\hline \multicolumn{1}{|c|}{ ST1 (Alcott 1868-1869/2005) } & \multicolumn{1}{c|}{$\begin{array}{c}\text { TT2 (Alcott 1868-1869/2004, } \\
\text { translated by Méndez) }\end{array}$} & Strategy \\
\hline 22) & $\begin{array}{l}\text { But tears were unmanly weakness } \\
\text { (p. 84) }\end{array}$ & $\begin{array}{l}\text { pero el llanto era una debilidad } \\
\text { impropia de un carácter masculino } \\
\text { (p. 129) }\end{array}$ & No change \\
\hline 23) & $\begin{array}{l}\text { Jo in maroon, with a stiff, gentlemanly } \\
\text { linen collar (p. 33) }\end{array}$ & $\begin{array}{l}\text { Jo iba de granate, con un cuello de lino } \\
\text { almidonado de estilo masculino (p. 51) }\end{array}$ & Alteration \\
\hline 24) & $\begin{array}{l}\text { Laurie's bashfulness soon wore off, for } \\
\text { Jo's gentlemanly demeanor amused } \\
\text { and set him at his ease, [...]. (p. 36-37) }\end{array}$ & $\begin{array}{l}\text { Laurie no tardó en superar su timidez, } \\
\text { porque la actitud masculina de Jo le } \\
\text { divertía y le hacía sentirse cómodo. } \\
\text { (p. 56) }\end{array}$ & Alteration \\
\hline
\end{tabular}

Later on in the novel, the narrator's comments on the characters allow readers to achieve a more complete picture of the four sisters. Since the narrator is extradiegetic and omniscient, his or her viewpoint is particularly important as it seems to provide a more detached, and therefore objective, interpretation of the characters' personalities and physical appearance. Let us consider Jo's description in example 25: 
TABLE 10

Narrator's comments

\begin{tabular}{|c|c|c|c|}
\hline & ST1 (Alcott 1868-1869/2005) & $\begin{array}{l}\text { TT2 (Alcott } 1868-1869 / 2004, \\
\text { translated by Méndez) }\end{array}$ & Strategy \\
\hline 25) & $\begin{array}{l}\text { Fifteen-year-old Jo was very tall, } \\
\text { thin and brown, and reminded one } \\
\text { of a colt }^{(\mathrm{a})} \text {; for she never seemed to } \\
\text { know what to do with her long } \\
\text { limbs, which were very much in her } \\
\text { way }^{(\mathrm{b})} \text {. She had a decided mouth, a } \\
\text { comical nose }^{(\mathrm{c})} \text {, and sharp gray eyes, } \\
\text { which appeared to see everything, } \\
\text { and were by turns fierce, funny, or } \\
\text { thoughtful. Her long, thick hair was } \\
\text { her one beauty }{ }^{(\mathrm{d})} \text {; but it was usually } \\
\text { bundled into a net, to be out of her } \\
\text { way. Round shoulders had Jo, big } \\
\text { hands and feet, a fly-away look to } \\
\text { her clothes, and the uncomfortable } \\
\text { appearance of a girl who was } \\
\text { rapidly shooting up into a woman }{ }^{(e)} \\
\text { and didn't like it. (p. 10) }\end{array}$ & $\begin{array}{l}\text { A sus quince años, Jo era muy alta, } \\
\text { delgada y morena, y tenía un aspecto } \\
\text { desgarbado que recordaba al de un } \\
\text { potrillo, como si no supiese qué } \\
\text { hacer con sus largos brazos y piernas. } \\
\text { Su boca reflejaba un carácter } \\
\text { decidido, su nariz resultaba cómica } \\
\text { y sus ojos grises, perspicaces, no se } \\
\text { perdían un solo detalle y lanzaban } \\
\text { miradas unas veces fieras, otras } \\
\text { divertidas y, en ocasiones, } \\
\text { meditabundas. Su cabello, largo y } \\
\text { abundante, era su principal } \\
\text { atractivo, pero solía llevarlo recogido } \\
\text { con una redecilla para que no le } \\
\text { molestase. De hombros redondeados } \\
\text { y manos y pies grandes, Jo } \\
\text { acostumbraba a llevar ropas holgadas } \\
\text { y tenía el aspecto de una jovencita } \\
\text { que se volvía mujer a su pesar y no } \\
\text { se sentía cómoda en su nuevo papel. } \\
\text { (p. 18) }\end{array}$ & $\begin{array}{l}\text { (a) Addition } \\
\text { (b) Subtraction } \\
\text { (c) Alteration } \\
\text { (d) Alteration } \\
\text { (e) Alteration }\end{array}$ \\
\hline
\end{tabular}

In the fragment we observe a tendency to explicitation. Jo, who in ST1 reminded one of a colt, acquires, in TT2 un aspecto desgarbado que recordaba al de un potrillo (a clumsy look that reminds one of that of a colt). The translator also explicitates the psychological features that Jo's face seem to suggest (Su boca reflejaba un carácter decidido, su nariz resultaba cómica [her mouth reflected a firm character, her nose looked comical]) as well as her reaction to becoming a woman (tenía el aspecto de una jovencita que se volvía mujer a su pesar [she had the look of a young woman who was becoming a woman in spite of herself]), which translates the expression uncomfortable appearance. Finally, the segment which were very much in her way is omitted.

As for Mrs. March's description (example 26), the translation seems to semantically cling to ST1. To begin with, Méndez decides to keep the familiar nickname Marmee in the TT, probably to stress the originality of its form in the novel and sacrificing the direct association of Marmee with mommy. As we have already said, the description of this character in ST1 presents a less refined and less mundane image of Marmee than in ST2. The woman is stout instead of tall and not a particularly handsome person instead of a noble person. 


\begin{tabular}{|c|c|c|c|}
\hline & ST1 (Alcott 1868-1869/2005) & $\begin{array}{c}\text { TT2 (Alcott } 1868-1869 / 2004, \\
\text { translated by Méndez) }\end{array}$ & Strategy \\
\hline 26) & $\begin{array}{l}\text { "Glad to find you so merry, my } \\
\text { girls," said a cheery }{ }^{(\mathrm{a})} \text { voice at the } \\
\text { door, and actors and audience } \\
\text { turned to welcome a stout motherly } \\
\text { lady }{ }^{(\mathrm{b})} \text {, with a "can-I-help-you" look } \\
\text { about her which was truly } \\
\text { delightful }{ }^{(\mathrm{c})} \text {. She wasn't a } \\
\text { particularly handsome person (d), } \\
\text { but mothers are always lovely to } \\
\text { their children, and the girls thought } \\
\text { the gray cloak and unfashionable } \\
\text { bonnet covered the most splendid } \\
\text { woman in the world } \\
\text { (e)." (p. 13) }\end{array}$ & $\begin{array}{l}\text {-Me alegro de veros tan contentas, } \\
\text { hijas mías - dijo una voz risueña desde } \\
\text { la puerta, y actrices y público corrieron } \\
\text { a recibir a una señora robusta y } \\
\text { maternal; todo en ella parecía decir: } \\
\text { "¿Puedo ayudarle en algo», lo que le } \\
\text { daba un aspecto encantador. No era } \\
\text { especialmente bella, pero los hijos } \\
\text { siempre consideran agraciadas a sus } \\
\text { madres y, para aquellas jóvenes, la } \\
\text { mujer con el gorro pasado de moda y } \\
\text { el abrigo gris era la más espléndida } \\
\text { del mundo- (p. 23) }\end{array}$ & $\begin{array}{l}\text { (a) Alteration } \\
\text { (b) Alteration } \\
\text { (c) No change } \\
\text { (d) Alteration } \\
\text { (e) No change }\end{array}$ \\
\hline
\end{tabular}

To conclude, Méndez's translation presents no major change in the character's description. This translation strategy, which seems to dominate the whole work, makes it possible to reproduce Mrs. March's image in its great variety of features, which, at times, are contradictory. In this way, the translation also reproduces the ST's ambivalent reading of the character.

\section{What a contrastive analysis can reveal about translation and gender}

The lengthy analysis of ST1 and ST2 and their translations allows us to formulate some conclusive remarks. Firstly, our theoretical reflections on the translation of Literature for Children and on the translation of gender in this literary subsystem have made it possible to understand which parts of the text may lend themselves better than others to manipulation during translation. We have thus observed that the ambivalent character of Literature for Children, which addresses both children and adults, and the ambiguity and ambivalence of the image of womanhood as a social gender in the novel, to whom both progressive and conservative features may be attributed, represent the interlocutory space in which translators have worked in order to adapt their translations to the conventions imposed by the target sociocultural context. Our initial hypothesis has been confirmed by the analysis of both translations. In the 1948 version, the translation agents (translator, editor, publisher) used the ambivalence of the image of womanhood as a manipulation space that allowed them to present an image that is much closer to Francoist ideology. The translation attenuated the progressive facets of the image of womanhood by downplaying or omitting altogether, in the case of Jo, the masculine features of her personality and body. The image of womanhood as the angel of the house was exalted in the translation of Mrs. March's character and of Jo's sisters through the use of diminutives. This stylistic device leads to an infantilization of women, who are deprived of authority and independence. It also defines the narrator's point of view, which can be envisioned as more authoritarian and patronizing. The study confirms our hypothesis according to which the narrator's voice, more than any character's voice, lends itself better to this change in point of view, at least in this novel. This observation also allows us to formulate a new hypothesis, which further studies need 
to verify, which proposes that any perspectival change leads to a change in the perception of the narrator's social gender. More specifically, the identification of the ST narrator with a woman, and with Alcott herself, is not always as straightforward in the TT due to its patronizing attitude which may evoke masculine behaviours of a traditional patriarchal society.

In the case of the 2004 translation there seems to be an inverse trend. The somewhat militant position of the translator, which can be inferred from the introductory words and from her wish to finally offer Spanish readers an uncensored, unsweetened version of Mujercitas, produces a translation that clings to the 1868 ST. We even observe an attenuation of infantilizing elements present in the ST. This phenomenon is particularly evident in the use that Méndez makes of the terms masculine or feminine, which belong to a neutral register, in order to translate adjectives with childish connotations such as boyish, tomboy or girlish. We also observed the omission of the analytical diminutive little. Finally, a number of explicitations seem to point to Méndez's use of the ambivalence of the image of womanhood in Alcott's original text in order to direct it, maybe unconsciously, to a progressive discourse that is in agreement with the current social awareness on gender issues and with the dominant ideology in the Spanish sociocultural context of our time.

\section{NOTES}

1. The source text includes two volumes published separately in 1868 and 1869, and later grouped in a single book in 1880. [ST1] corresponds to the 2005 edition published by the Library of America.

2. Incidentally, 2018 and 2019 mark the 150-year anniversary of the publication of part one and part two of the book. This event also led to the release of a 2018 film, titled Little Women and directed by Clare Niederpruem (a modern time adaptation of the book for the cinema), and an upcoming classical Hollywood film adaptation with the same title, directed by Greta Gerwig with well-known actors such as Saoirse Ronan, Emma Watson, Timothée Chalamet, Laura Dern, and Meryl Streep.

3. In our study we analyse only the first part of the book, since the 1948 translation [TT1] does not include the second part.

4. Probably on the occasion of the 150-year anniversary of the publication of the first part of Little Women in the USA, a new translation into Spanish by Alonso Valle was published by AKAL, which we could not analyse since we had already completed our study.

5. On gender studies, see Litosseliti and Sunderland (2002), and Holmes and Meyerhoff (2003), among many others.

6. Von Flotow (2011: 5-9) observes, however, that Butler's theory of performativity is deterministic although it has been interpreted in a more proactive way by other scholars such as Parker and Kosofsky Sedgwick (1995).

7. We use as [ST2] the 2017 reedition of the 1880 single volume release of the book.

8. Here are the fragments: [ST1] "a nervous, fussy old lady, who [...] worries you till you you're ready to fly out the window or box her ears?" (Alcott 1868-1869/2005: 8); [ST2] "a nervous, fussy old lady, who [...] worries you till you you're ready to fly out the window or cry?" (Alcott 1880/2017: 3); [TT1] "una vieja histérica y caprichosa que [...] os fastidia hasta que os entran deseos de echaros a llorar o saltar por el balcón?" (Alcott 1880/1948: 26); [TT2] "una anciana histérica y tiquismiquis que [...] te da tanto la lata que al final te entran ganas de abofetearla o de escapar por la ventana?" (Alcott 1868-1869/2004: 15).

9. For a recent critical revision on this issue see Molés-Cases (2016: 62-102). For the difference between the notion of strategy and that of technique see Molina and Hurtado Albir (2002: 507-508).

10. For a bibliographical overview see Lyon Clark and Hendrickson (1999).

11. See Hernández Socas and Giugliano (2019).

12. The textual tradition concerning the formation, use and frequency of diminutives varies between English and Spanish. In English we rarely find synthetic diminutives, which, conversely, are common in Spanish. Diminutives in English are commonly formed by using analytic markers such as little and tiny, as can be seen in the very title of Alcott's novel (Veidenberga 2014: 176). In English, 
synthetic, rather than analytic diminutives evoke nursery rhymes and children language. It seems significant to observe that in Italian, in which diminutives function in a similar way as in Spanish, the title has been translated with an analytic diminutive (Piccole donne), which seems to suggest the same variety of meanings as in the ST even though this construction is less usual. In French, on the other hand, the title is not Petites femmes but Les quatre filles du docteur March.

13. Fernández López, Marisa (18 November 2017): personal communication, e-mail. We would like to thank Prof. Fernández López for her prompt reply to our questions and for the information provided on the censored translations.

14. Real Academia Española y Asociación de Academias de la Lengua Española (2010): Nueva Gramática de la lengua española. Manual. Madrid: Espasa Calpe, 168-169.

15. Real Academia Española y Asociación de Academias de la lengua Española (2018): Diccionario de la lengua española. Consulted 5 May $2018<$ http://dle.rae.es>.

16. The fall of post-vocalic $r$ started in England in the second half of the $18^{\text {th }}$ century and became an established phonetic trait in the $19^{\text {th }}$ century in southern England. English pronunciation was considered a model of correct pronunciation in the USA at least until the beginning of the twentieth century. As a consequence, in New England the term marmee would have been pronounced [m'a:mi] in Alcott's time and would be a homophone of mommy.

17. It should be stressed, however, that the textual manipulations and changes of the 1868-1869 text in the 1880 edition are not so drastic as the translator's note seems to suggest (Alberghene and Lyon Clark 1999: xxxii). Despite what Méndez (2004: 8) argues, both texts present the same number of chapters. Moreover, even though textual differences do exist, they only affect short segments of the novel, although these may certainly affect the way readers perceive the image of the characters in both editions.

\section{REFERENCES}

Aвате, Michelle Ann (2008): Tomboys: A Literal and Cultural History. Philadelphia: Temple University Press.

Alvstad, Cecilia (2008): Ambiguity Translated for Children: Andersen's 'Den standhaftige Tinsoldat' as a Case in Point. Target. 20(2):222-248.

Alberghene, Janice M. and Lyon Clark, Beverly, eds. (1999): Little Women and the Feminist Imagination. New York/London: Taylor \& Francis Group.

ButLer, Judith (1990): Gender Trouble: Feminism and the Subversion of Identity. London/New York: Routledge.

De Beauvoir, Simone (1949/1953): The Second Sex. (Translated from French by Howard M. PARShley) London: John Cape.

Desmidt, Isabelle (2006): A Prototypical Approach within Descriptive Translation Studies? Colliding Norms in Translated Children's Literature. In: Jan VAN CoILliE and Walter P. Verschueren, eds. Children's Literature in Translation: Challenges and Strategies. Manchester: St. Jerome, 79-96.

Estes, Angela M. and Lant, Kathleen M. (1989): Dismembering the text: The Horror of Louisa May Alcott's Little Women. Children's Literature. 17:98-123.

Fetterley, Judith (1979): Little Women: Alcott's Civil War. Feminist Studies. 5:369-383.

Fernández LóPez, Marisa (2000): Comportamientos censores en literatura infantil y juvenil: Traducciones del inglés en la España franquista. In: Rosa RABADÁN, ed. Traducción y censura, inglés-español 1939-1985. León: Universidad de León, 227-253.

Fernández LóPez, Marisa (2007): Comportamientos censores en la literatura infantil y juvenil traducida del inglés en la época franquista: establecimiento de un corpus textual. In: Raquel Merino Álvarez, ed. Traducción y censura en España (1939-1985): estudios, sobre corpus TRACE: cine, narrativa, teatro. Bilbao: Universidad de León/Universidad del País Vasco, 19-48.

Grasso, Linda (1998): Louisa May Alcott's “Magic Inkstand”: Little Women, Feminism, and the Myth of Regeneration. Frontiers: A Journal of Women Studies. 19(1):177-192.

Heritier, Monique (2008): La femme espagnole: de la femme au foyer a la preneuse de décisions. Proyecto social: Revista de relaciones laborales. 12(12):120-142. 
Hernández Socas, Elia and Giugliano, Marcello (2019): La recepción de Little Women en España a través de sus traducciones y adaptaciones. Quaderns. Revista de Traducció. 26:137160.

Holmes, Janet and Meyerhoff, Miriam, eds. (2003): The Handbook of Language and Gender. Oxford: Blackwell Publishing.

Le Brun, Claire (2003): De Little Women de Louisa May Alcott aux Quatre filles du docteur March: Les traductions françaises d'un roman de formation au féminin. Meta. 48(1-2):47-67.

Litosseliti, Lia and Sunderland, Jane (2002): Gender Identity and Discourse Analysis: Theoretical and Empirical Considerations. In: Lia Litosseliti and Jane Sunderland, eds. Gender Identity and Discourse Analysis. Amsterdam/Philadelphia: John Benjamin, 1-39.

Llompart Pons, Auba (2016): Censoring gender: Translations of Louisa May Alcott's Little Women in Franco's Spain. In: Pedro C. Cerrillo Torremocha and César Sánchez Ortiz, eds. Prohibido leer: La censura en la literatura infantil y juvenil contemporánea. Cuenca: Ediciones de la Universidad de Castilla-La Mancha, 61-69.

Lyon Clark, Beverly and Hendrickson, Linnea (1999): Selected Bibliography of Alcott Biography and Criticism. In: Janice M. Alberghene and Beverly Lyon Clark, eds. Little women and the Feminist Imagination: Criticism, Controversy, Personal Essays. New York/London: Garland, 381-420.

Manrique Arribas, Juan Carlos (2003): La Educación Física femenina y el ideal de mujer en la etapa franquista. Revista Internacional de Medicina y Ciencias de la Actividad Física y el Deporte. 3(10):83-100.

Martens, Hanna, Soto Vázquez, José and Fernández, Ramón Tena (2016): El estudio de la censura de libros infantiles en la España franquista. In: Pedro C. Cerrillo Torremocha and César SÁnchez Ortiz, eds. Prohibido leer: La censura en la literatura infantil y juvenil contemporánea. Cuenca: Ediciones de la Universidad de Castilla-La Mancha, 43-51.

Méndez, Gloria (2004): Nota del editor. In: Louisa May Alcotт. Mujercitas. (Translated from English by Gloria Méndez) Madrid: Debolsillo, 7-8.

Molés-CASEs, Teresa (2016): La traducción de los eventos de movimiento en un corpus paralelo alemán-español de literatura infantil y juvenil. Frankfurt am Main: Peter Lang.

Molina, Lucía and Hurtado Albir, Amparo (2002): Translation Techniques Revisited: A Dynamic and Functionalist Approach. Meta. 47(4):498-512.

Murphy, Ann (1990): The Borders of Ethical, Erotic, and Artistic Possibilities in "Little Women." Signs. The Ideology of Mothering: Disruption and Reproduction of Patriarchy. 15(3):562-585.

NidA, Eugene A. (1964): Toward a Science of Translating with Special Reference to Principles and Procedures Involved in Bible Translating. Leiden: E.J. Brill.

Oittinen, Riitta (2000): Translating for Children. London/New York: Garland.

O'Sullivan, Emer (2013): Children's literature and translation studies. In: Carmen Millán and Francesca BARTrina, eds. The Routledge Handbook of Translation Studies. London/New York: Routledge, 451-463.

Parker, Andrew and Kosofsky Sedgwick, Eve (1995): Introduction: Performativity and Performance. In: Andrew Parker and Eve Kosofsky Sedgwick, eds. Performativity and Performance. London/New York: Routledge, 1-18.

Sánchez Ortiz, César (2016): Presentación. In: Pedro C. Cerrillo Torremocha and César SÁnchez Órtiz, eds. Prohibido leer: La censura en la literatura infantil y juvenil contemporánea. Cuenca: Ediciones de la Universidad de Castilla-La Mancha, 13-14.

Shavit, Zohar (1986/2009): Poetics of Children's Literature. Athens/London: The University of Georgia Press.

Showalter, Elaine (2005): Note on the texts. In: Louisa May Alcotт. Little Women, Little Men, Jo's Boys. (Edited by Elaine SHowalter) New York: Library of America, 1078-1080.

Simon, Sherry (1996): Gender and Translation. London/New York: Routledge.

ТАLвот, Mary (2003): Gender Stereotypes: Reproduction and challenge. In: Janet Holmes and Miriam Meyerhoff, eds. The Handbook of Language and Gender. Oxford: Blackwell Publishing, 468-486. 
Veidenberga, Zane (2014): Transfer of Implied Values of the Latvian Diminutives into Their English Language Counterparts. In: Abdel Wahab Khalifa, ed. Translators Have Their Say? Translation and the Power of Agency: Selected Papers of the CETRA Research Summer School 2013. Zürich/Berlin: Lit-Verlag, 174-194.

Von Flotow, Luise (2001): Gender in Translation: The Issues Go on. Orées. 2:17p. Consulted 25 August 2019, <http://elmbsm193.yolasite.com/resources/gender\%20in\%20translation\%20 studies\%20by\%20lori\%20chamberlain.doc $>$.

Von Flotow, Luise (2011): Translating Women. Ottawa: University of Ottawa Press.

WoDAK, Ruth (1997): Gender and Discourse. London: Sage.

Yuval-Davis, Nira (1997): Gender and Nation. London: Sage.

\section{APPENDIX}

\section{Corpus}

Alcotт, Louisa May (1868): Little Women, or Meg, Jo, Beth and Amy. Vol. 1. Boston: Roberts Brothers.

Alcotт, Louisa May (1869): Little Women, or Meg, Jo, Beth and Amy. Vol. 2. Boston: Roberts Brothers.

Alcotт, Louisa May (1880): Little Women. Cambridge: John Wilson and Son.

Alсотt, Louisa May (1880/1948): Mujercitas. (Translated from English by Enriqueta S. Albanella) Madrid: Molino.

Alcotт, Louisa May (1868-1869/2004): Mujercitas. (Translated from English by Gloria Méndez) Madrid: Debolsillo.

Alсотт, Louisa May (1868-1869/2005): Little Women. In: Louisa May Alcotт. Little Women, Little Men, Jo's Boys. (Edited by Elaine SHOwALter) New York: Library of America, 1-517. Alсотт, Louisa May (1880/2017): Little Women. Seattle: Amazon Classics. 